\title{
THE REGULATORY BURDEN IN THE SWISS WEALTH MANAGEMENT INDUSTRY
}

Christian Bührer (buehrer@isb.unizh.ch)

Tel.: +41-44-634-45-83, Fax.: +41-44-634-49-03

Ivo Hubli (ivo.hubli@gmx.ch), and

Tel.: +41-55-417-75-00, Fax.: +41-44-634-49-03

Eliane Marti (elianemarti@freesurf.ch)

Tel.: +41-44-361-03-51, Fax.: +41-44-634-49-03

Swiss Banking Institute, University of Zürich,

Plattenstrasse 14, 8032 Zürich, Switzerland

\section{Introduction}

In the recent past, regulatory costs have received a great deal of attention within the Swiss wealth management industry. On the one hand, financial institutions are intensifying their focus on cost management in general, due to the plunge of fees and commissions since the bubble burst on global equity markets. On the other hand, wealth management institutes are faced with rapidly increasing regulatory requirements, leading to a significant rise in their regulatory costs.

Neither in theory nor in practice is there any doubt regarding the economic rationale and the necessity for regulation in the financial industry. Basically, bank regulation is justified as a means of preventing potential market failures in the financial sector,[1] in order to protect depositors and the financial system as a whole.[2] The characteristics of the wealth management business, such as agency problems and asymmetric information, may lead to risky behaviour on the part of wealth management institutes and potential losses for depositors and investors.[3] A crisis in a single financial institute may easily lead to a crisis of confidence in the whole sector, with harmful consequences on monetary transactions and other industries within an economy.[4]

Additionally, regulators and supervisors are paying a great deal of attention to protecting the reputation of the financial industry and financial centres. The prevention of activities such as money laundering and the financing of terrorism is of paramount importance within this context.[5]

Yet, despite the positive effects of these regulatory interventions, their cost has to be considered, too. In fact, it is only if the overall benefits of regulation exceed its cost that regulation ultimately yields a profit. Attempts to quantify the cost of regulation can be found in the U.S. and the U.K. In Switzerland, however, there is still a lack of information on the regulatory burden of financial institutions.

\section{Review of the Literature}

Theoretical aspects of regulation in general, as well as the specific regulation of the financial system, are widely covered in the literature. Furthermore, 
several articles in both academic and practical journals discuss the optimum extent of regulation and the advantages and drawbacks of regulatory systems. Nevertheless, there have been only a few attempts in the literature to quantify regulatory costs, most likely owing to the difficulty of assessing them quantitatively.

Elliehausen's (1998) review paper provides an interesting overview of 15 U.S. studies from 1976 to 1994 regarding regulatory costs. It questions the statistical significance of many of the results, but still provides a valuable insight into the quantitative world of regulatory costs.

In 1998, Franks, Schaefer and Staunton investigated the regulatory burden of British brokers and investment management firms. Among other results, they quantified the regulatory burden as GBP 2'135 and GBP 2'690 per capita, respectively. In 2003, a study by Europe Economics analysed the cost of the British regulatory system and showed that the prevention of money laundering accounts for the greater part of the total regulatory burden. The Swiss Federal Banking Commission (SFBC) annually surveys the auditing costs of Swiss financial institutes. The results show a clear trend of continuously increasing regulatory costs for auditing issues and strong economies of scale.

\section{Methodology}

In the autumn of 2003, the Swiss Banking Institute of the University of Zürich (ISB) initiated a series of studies[6] on the regulatory burden of Swiss wealth management institutes for the year 2002. The primary aim of these studies was to compare the impact of regulation on the costs of different regulatory frameworks applicable to the provision of wealth management services. The empirical measurement of these expenses is based on a framework set up by the British Financial Services Authority (FSA). The FSA is obliged to assess the economic costs and benefits of each proposed policy, by carrying out a Cost Benefit Analysis
(CBA).[7] Thus, it tries to avoid the implementation of regulations whose additional benefits are offset by supplementary costs.[8]

In contrast to such a CBA, the studies conducted by the ISB clearly focus on the assessment of regulatory costs, while benefits are not quantified. The participants in the survey were merely asked to rank the different fields of regulation according to their importance for the Swiss financial industry, in order to assess their relative benefits.

The cost categories in the ISB studies follow the CBA framework of the FSA, which distinguishes between direct, compliance and indirect costs.

Direct costs comprise the resources needed within the body of the financial regulator to design, monitor and enforce regulations. In the U.K., costs for ongoing supervision are incurred by the FSA and are regarded as direct costs. In Switzerland, however, a certain degree of supervisory responsibility is delegated to designated auditing companies. The ISB studies define these costs as a new cost category called incremental auditing costs, since the Swiss "dual supervision system" forces external auditors to fulfil ongoing supervisory functions. According to the SFBC, this bucket includes external and internal incremental auditing costs, whereas incremental costs only comprise costs which would not have been incurred in the absence of regulation.

Compliance costs are the costs incurred by financial institutes as a result of activities required by regulators.[9] Again, the focus lies on the incremental part of the costs, which of course is a subjective and often difficult quantity to delimit.

Compared to the FSA framework, the ISB studies do not quantify the least obvious, hard-to-measure indirect costs. Indirect costs are opportunity costs and arise from missed income, reduced competition and loss of business to other, less regulated countries.[10]

Consequently, the ISB studies distinguish between the following cost categories: (1) direct costs, (2) incremental auditing costs and (3) compliance costs. 


\section{Data}

The data used were gathered through questionnaires. The drawbacks of this approach, such as potential misunderstanding of the questions, were mitigated by intense consultation of experts during the design and realisation phases. The results are based on responses from 48 Swiss wealth management institutes, comprising 17 members of the Association of Swiss Commercial and Investment Banks (ASCB), 10 members of the Association of Swiss Private Bankers (ASPB) and 21 Securities Dealers (SD). The information about Independent Asset Managers (IAM) is based on 371 responses and estimates of their regulatory burden. Table 1 shows the number, the average headcount and the range of headcounts within the institutes described. From a statistical point of view, the size of the sample is rather too small to assign reliability to the results. In addition, the difficulty of estimating the cost of regulation, and especially of delimiting the incremental part, was a very likely source of data bias. The quality of the data was therefore assessed carefully.

In the first place, several control questions were incorporated into the questionnaires in order to allow quality as well as consistency checks. Secondly, a large number of consistency tests were carried out in order to uncover potential bias and distortions of the sample data (e.g., through outliers); the outcomes of these tests confirmed the scale of the findings.[11] Finally, the results were compared with findings from other studies, such as the SFBC survey on the auditing costs of Swiss fi- nancial institutes, which again confirm the scale of the results.[12] The conclusion of the quality assessment is that the quality of the data is satisfactory, and that the data are able to reveal both the basic characteristics and the scale of the regulatory burden of the wealth management firms analysed. Within the scope of the ISB studies, the ASCB Banks, Private Bankers and SDs questioned were invited to assess the costs and benefits of seven regulatory fields in a qualitative manner. Table 2 illustrates the cost-benefit ranking and the resulting ranking differences for the specific regulatory fields.

The greatest costs arise in those regulatory fields where the benefits seem to be highest. This is shown by the rank correlation coefficients. The largest gap between costs and benefits is exhibited by the regulatory field of equity/liquidity/accounting, and is especially pronounced for SDs.

\section{The Four Regulatory Frameworks in Wealth Management}

In Switzerland, wealth management can be conducted through various regulatory frameworks: Wealth Management Banks, Private Bankers, Security Dealers (SD) and Independent Asset Managers (IAM).

Banks are subject to the strictest regulation and supervision, based on the Federal Banking Act (FBA), the ordinance to the Federal Banking Act (FBO), the guidelines of the SFBC, and selfregulation. The law basically sees a bank as an

Table 1: Number of Providers and Average Headcount of the Different Regulatory Frameworks

\begin{tabular}{lcccc}
\hline Regulatory Framework & Number of Providers & Sample & Average Headcount & Headcount: Range \\
\hline Bank (ASCB members only) & 30 & 17 & 280 & $14-2274$ \\
Private bankers & 15 & 10 & 240 & $43-1661$ \\
$\begin{array}{l}\text { Securities dealer } \\
\text { (without banking license) }\end{array}$ & 65 & 21 & 26 & $3-96$ \\
Independent asset manager & 2 '000-2'500 & $(371)$ & 4 & $1-200$ \\
\hline
\end{tabular}

Sources: ASPB, BÜHRER (2004), HUBLI (2004), MARTI (2004), SAAM, SFBC (2004b), SNB (2004). 
Table 2: Cost-Benefit Ranking for Different Regulatory Fields

\begin{tabular}{|c|c|c|c|c|c|c|c|c|c|}
\hline \multirow[b]{2}{*}{ Regulatory fields } & \multicolumn{2}{|c|}{$\begin{array}{l}\text { ASCB } \\
\text { Banks } \\
\end{array}$} & \multicolumn{2}{|c|}{$\begin{array}{c}\text { Private } \\
\text { Bankers } \\
\end{array}$} & \multicolumn{2}{|c|}{$\begin{array}{c}\text { Securities } \\
\text { Dealer }\end{array}$} & \multirow{2}{*}{$\begin{array}{c}\text { ASCB } \\
\text { Banks } \\
\text { Ranking } \\
\text { difference }\end{array}$} & \multirow{2}{*}{$\begin{array}{c}\text { Private } \\
\text { Bankers } \\
\text { Ranking } \\
\text { difference }\end{array}$} & \multirow{2}{*}{$\begin{array}{c}\text { Securities } \\
\text { Dealer } \\
\text { Ranking } \\
\text { difference }\end{array}$} \\
\hline & $\begin{array}{l}\text { Cost } \\
\text { rank }\end{array}$ & $\begin{array}{l}\text { Benefit } \\
\text { rank }\end{array}$ & $\begin{array}{l}\text { Cost } \\
\text { rank }\end{array}$ & $\begin{array}{c}\text { Benefit } \\
\text { rank }\end{array}$ & $\begin{array}{l}\text { Cost } \\
\text { rank }\end{array}$ & $\begin{array}{c}\text { Benefit } \\
\text { rank }\end{array}$ & & & \\
\hline $\begin{array}{l}\text { Prevention of } \\
\text { money laundering }\end{array}$ & 1 & 1 & 1 & 1 & 2 & 1 & 0 & 0 & 1 \\
\hline Risk management & 3 & 4 & 4 & 5 & 3 & 2 & -1 & -1 & 1 \\
\hline $\begin{array}{l}\text { Equity/liquidity/ } \\
\text { accounting }\end{array}$ & 2 & 4 & 2 & 2 & 1 & 4 & -2 & 0 & -3 \\
\hline Market behaviour & 4 & 3 & 3 & 2 & 4 & 3 & 1 & 1 & 1 \\
\hline $\begin{array}{l}\text { Independence of } \\
\text { financial analysis }\end{array}$ & 7 & 7 & 7 & 6 & 7 & 5 & 0 & 1 & 2 \\
\hline $\begin{array}{l}\text { Guidelines on } \\
\text { portfolio } \\
\text { management } \\
\text { agreements }\end{array}$ & 5 & 2 & 5 & 2 & 5 & 6 & 3 & 3 & -1 \\
\hline Fund distribution & 6 & 6 & 6 & 6 & 6 & 7 & 0 & 0 & -1 \\
\hline $\begin{array}{l}\text { Spearman rank } \\
\text { correlation } \\
\text { coefficients }\end{array}$ & & & & & & & 0.73 & 0.79 & 0.68 \\
\hline
\end{tabular}

Sources: HUBLI (2004), MARTI (2004).

enterprise which operates in the classic business of interest margins; thus, the regulatory concept for banks is directed primarily at commercial banking and the limitation of inherent risks. In Switzerland, the system of universal banks prevails. This allows banks - if they so wish - to participate in all banking businesses. Nevertheless, there are many banks which focus on particular business opportunities. The 30 ASCB Banks are mainly active in wealth management, are organised as stock corporations and have a securities dealer's license. On average, these banks have 280 employees.

The Private Banker status is regulated by the FBA. The legal status of such institutes covers sole ownership, registered partnership, limited partnership and limited partnership with shares. The specific status of Private Bankers is characterised by the presence of at least one partner with unlimited liability for the bank's commitments. Based on the unlimited and joint liability of the participators, they benefit from certain regulatory privileges and thus wear a somewhat looser regulatory corset than other banks. Private Bank- ers who do not advertise publicly enjoy a certain relief with regard to their capital surplus accumulation and are not obliged to publish their balance sheet and income statement. Their civil law responsibility is regulated in the Swiss code of obligations (CO), and is thus different from that which applies to stock corporation banks. Private Bankers are not subject to double taxation as stock corporations are, but face disadvantages in the area of income tax and social security contributions: the total earnings of partnership companies - even if reinvested-are subject to income tax and to pension and public social security payments. Social security contributions are deducted not only from salaries, but also from total earnings.[13] In Switzerland, there exist 15 Private Bankers employing an average of 240 persons each. Securities Dealers $(S D)$ are regulated through the Federal Act on Securities Exchanges and Securities Trading (SESTA). The associated ordinance and a circular drawn up by the SFBC define five categories of SD: own-account dealers, issuing houses, derivative houses, market makers and client deal- 
ers, the last-named being predominately active in the wealth management business. The regulation of the SDs is very similar to bank directives and is the same for all categories. Whereas SDs are allowed to make loans (e.g., lombard credits) and keep deposits and custody accounts, only banks are allowed to offer interest on clients' accounts. Thus, SDs are not allowed to operate in the interest margin business. The auditing rules and licensing regulations are equally applicable to SDs and banks; an important difference, however, concerns the minimum capital prerequisites, since SDs have to raise at least CHF 1.5 millions, compared to a CHF 10 millions requirement for banks. Regarding special regulatory rules[14], which are particularly relevant in wealth management, there are no major differences between the regimes of SDs and banks. In Switzerland, there are 65 SDs without banking licenses, with an average headcount of 26.

In Switzerland, 2'000 to 2'500 Independent Asset Managers (IAM) function as financial intermediaries between private clients and banks; they operate with an average headcount of approximately 4 . IAMs are subject to the $\mathrm{CO}$, but they are not subject to prudential[15] regulation. Authorisation is nonobligatory for IAMs to carry out their business.[16] Neither the banking secrecy rules nor the broadly similar professional secrecy rules for SDs apply to IAMs.[17] All IAMs are regulated through the Federal Act on the Prevention of Money Laundering in the Financial Sector (MLA). They are supervised either by intermediaries' recognised self-regulating bodies or by the federal control authority to combat money laundering (control authority). Some professional associations such as the Swiss Association of Asset Managers (SAAM) have binding codes of professional ethics for their members.[18] In contrast to the other regulatory frameworks, IAMs are not authorised to keep accounts or deposits. Consequently, their clients' assets are placed in the custody of a bank. IAMs are responsible to their clients for loyal and accurate accomplishment of the assigned mandate. If assets are invested on the basis of improper conflicts of interest (e.g., churning, violation of the portfolio management guidelines, scalping or front running) liability for damages may result from the $\mathrm{CO}$ and from Swiss Penal Law.[19]

\section{Regulatory Costs}

The regulatory burden basically depends on three factors. Firstly, it is influenced by the institute's regulatory status. Secondly, the institute's primary activity (i.e., securities trading, wealth management, fund distribution, etc.) plays a major role. Thirdly, the size of the firm is important, because of distinctive economies of scale.

The costs of regulation (CHF per capita year 2002) for ASCB Banks, Private Bankers and SDs are illustrated in Table 3. The ASCB Banks have additionally been subdivided into large and small corporations, with a threshold level of 100 employees being taken as the distinction between the two subcategories. The SDs, all of whom employ fewer than 100 persons, have been subdivided with regard to their main activity (wealth management or securities trading).

The regulatory burden for the IAMs has not been analysed systematically, and only estimates are available. Generally, it is difficult to estimate the regulatory burden of IAMs, as they vary widely with regard to size, legal structure and activity. The total regulatory burden per capita for IAMs is around CHF 6'800; this figure is made up of about CHF 3'000 compliance costs, about CHF 2'700 incremental auditing costs and about CHF 1'100 direct costs. These figures are underpinned by inputs from representatives of a few self-regulating bodies, the control authority and several IAMs. In 2003, the University of St. Gallen surveyed 500 Swiss IAM companies with regard to the total regulatory costs that arise from the prevention of money laundering (other incremental regulatory costs excluded). The average cost for the responding companies was CHF 20'000. Assuming a company has four employees, the cost 
Table 3: The Costs of Regulation in Wealth Management

\begin{tabular}{|c|c|c|c|c|c|}
\hline $\begin{array}{l}\text { Regulatory Burden } \\
2002 \text { [CHF per capita] }\end{array}$ & $\begin{array}{c}A S C B \\
\text { Banks-large }\end{array}$ & $\begin{array}{c}A S C B \\
\text { Banks-small }\end{array}$ & $\begin{array}{l}\text { Private } \\
\text { Bankers }\end{array}$ & $\begin{array}{c}\text { Securities } \\
\text { Dealer-Wealth } \\
\text { Management }\end{array}$ & $\begin{array}{c}\text { Securities } \\
\text { Dealer_Securities } \\
\text { Trading }\end{array}$ \\
\hline Regulatory burden & $12 ' 154$ & $28^{\prime} 734$ & 6’938 & $18^{\prime} 580$ & $14^{\prime} 161$ \\
\hline Compliance costs & $10 ’ 935$ & 24'270 & 6’412 & $15 ’ 255$ & $11 ' 568$ \\
\hline $\begin{array}{l}\text { Prevention of money } \\
\text { Laundering }\end{array}$ & $5 ’ 059$ & $8 ’ 374$ & 2746 & 4'936 & 145 \\
\hline Risk management & 2'472 & 3'458 & 1'002 & 2'372 & 4'825 \\
\hline Equity/liquidity/accounting & $1 ' 561$ & $5 ' 400$ & 829 & 2'107 & 4’508 \\
\hline Others & $1 ' 843$ & 7’038 & 1'835 & $5 ’ 840$ & 2'090 \\
\hline Incremental auditing costs & 1'157 & 4'327 & 440 & 3’039 & 1'979 \\
\hline External auditing costs & 357 & $1^{\prime} 600$ & 145 & 2'174 & 1’057 \\
\hline Internal auditing costs & 800 & $2 ' 727$ & 295 & 865 & 922 \\
\hline Direct costs & 62 & 137 & 86 & 286 & 614 \\
\hline
\end{tabular}

Sources: HUBLI (2004), MARTI (2004).

per capita would thus amount to CHF 5'000, which supports the estimated CHF 6'800 total regulatory burden for IAMs. Furthermore, it shows that almost all of the regulatory costs are generated by the prevention of money laundering. The total regulatory burden per capita amounts to approximately CHF 12'200 and CHF 28'700 for large and small ASCB Banks respectively, to CHF 7'000 for Private Bankers and to CHF 18'600 and CHF 14'200 for SDs.

Compliance costs make up the lion's share of the regulatory burden, representing at least $80 \%$ of the total charges. Compliance costs are highest for the small ASCB Banks, followed by the SDs and the large ASCB Banks; of all prudential-regulated frameworks, it is the Private Bankers who bear the lowest compliance costs. This ranking is more or less the same for all compliance subfields, such as the prevention of money laundering, risk management, equity/liquidity/accounting requirements, and others. The costs arising from the prevention of money laundering mainly make up the greater part of the compliance cost (except for SDSecurities Trading). This result is in line with other surveys showing that the initiatives of regulators and supervisors to prevent money laundering and the financing of terrorism have resulted in enormous increases in the burden of compliance.[20]
The incremental auditing costs are between $6 \%$ and $16 \%$ of the total regulatory burden; they are again highest for the small ASCB Banks, followed by the SDs, the large ASCB Banks and the Private Bankers. The proportion of external and internal auditing costs varies according to the regulatory framework: whereas, for the SD, the charges for the external audit are twice as high as for the internal one, the opposite is true in the case of ASCB Banks and Private Bankers.

Despite their increasing growth, the direct costs are of little importance compared to the other regulatory costs; they are highest for SDs, and only half as high for small ASCB Banks. Direct costs for Private Bankers and ASCB Banks are less than CHF 100 per capita.

\section{Recommendations}

In wealth management competition, market discipline and self-regulation are preferable to financial market regulation to guarantee system stability and the protection of depositors. Therefore, we recommend that enough space for self-regulation be created by the formulation of skeleton laws, in order to concentrate on the bottom line and thus to aim at an optimum regulatory density in terms of 
good practice" rather than "best practice" guidelines. The international "level playing field", implying compliance with certain common quality standards, should also be adhered to. However, it is important to ensure that Switzerland does not suffer from competitive disadvantages caused by overregulation compared to other countries. It must not be overlooked that many financial centres enjoy regulatory advantages which significantly boost their attractiveness and competitiveness. A "zero tolerance" philosophy, as intended by presentday Swiss regulation projects, will almost inevitably lead to high marginal costs which are not justified by marginal benefits in every case.[21]

The various regulation projects should be better coordinated in terms of content, time and systematics. Considering the differences between the various wealth management suppliers with regard to size and risk profiles, the regulatory design should be modular. Industry concentration caused by economies of scale in the area of auditing and compliance costs should be avoided. However, it is important to set limits to differentiation and to avoid high complexity because of the need for transparency.

On economic-political grounds, it seems desirable that the four regulatory concepts should explicitly differ in terms of costs and benefits, in order to provide real alternatives for the market participants. Analysis of the regulatory frameworks and the corresponding costs, however, reveals conceptual deficiencies in the regulatory design.

Banks benefit most from their regulatory status, which allows them to be active in all areas of the banking business and to profit from the prestige of their banking status. Small ASCB Banks bear the highest regulatory burden, with CHF 28'700 per capita. For large ASCB Banks however, the costs are much lower (CHF 12'200), even less than for SDs (CHF 14'200-18'600). In this context, a significant weakness of the Swiss regulatory regime becomes apparent: economies of scale favour large companies and discriminate against small financial institutes to a great extent.
Private Bankers benefit from certain regulatory privileges, and this is reflected in a significantly lower regulatory burden compared to banks and SDs. Additionally, Private Bankers profit from a high level of prestige and a good reputation among the public. As regards income tax and pension payments, Private Bankers-being partnership companies - are treated differently from corporations; it would be desirable for company taxation to be more neutral with regard to the different legal structures of companies. Overall, Private Banker status seems to be an attractive regulatory framework in the wealth management business.

The examinations prove a bank-equivalent regulatory burden for SD which seems to be rather high. However, a comparison between those SDs which predominately operate in wealth management and small ASCB Banks reveals substantially lower costs for the SDs (CHF 18'600 per capita). Nevertheless, it is recommended that regulation for SDs should be eased, in order to create a real alternative to the banking license, in particular for small providers. Furthermore, a differentiated treatment of the five existing SD categories would seem appropriate. At least non-account-keeping SDs should be relieved, especially with regard to equity guidelines and similar directives. Finally, the SDs should be exempted from a future Basel II regime.

On the basis of the limited range of services provided by IAMs, it is obvious that they incur the lowest regulatory costs of all four concepts. In their final report, the Zufferey group of experts (2000) proposed that IAMs be supervised prudentially. The Zimmerli group of experts analyzed the advantages and disadvantages of prudential supervision of IAMs, but the commission did not make any recommendations regarding their general supervision. In the U.S. and in European Union (EU) countries such as Germany and France, IAMs are supervised prudentially. It will become more and more difficult for Swiss IAMs to offer their services to customers in the EU without a 
license provided by a national regulator like the SFBC, as Swiss IAMs will face growing limitations on their cross-border business as a result of the lack of prudential regulation. Under the amended EU Directive on collective investments (UCITS fund guideline)[22], only supervised wealth managers are authorised to manage assets of an EU-domiciled investment fund. For this reason, there should at least be a possibility for Swiss IAMs to be supervised on a voluntary basis; otherwise, they will lose their share of the business with EU-domiciled investment funds.[23] Such voluntary supervision could be conducted on the basis of a modified SESTA or a new law for IAMs. For small IAMs who are not dependent on cross-border business and who would not be capable of bearing additional regulatory costs, a mandatory regime of prudential supervision could lead to extinction. In order to protect their customers against operational losses, these small IAMs could take out liability insurance to cover potential claims.[24] Both measures would lead to a better image for the IAM industry and strengthen the reputation of the Swiss financial industry as a whole.

In the future, regulations - and therewith the regulatory burden-will most likely increase further. Accordingly, banks and wealth management firms should examine whether their business processes still meet the regulatory requirements. Through innovative and joint solutions in areas such as transaction processing, education and ITapplications, the regulatory burden may be reduced, client relationship officers may be relieved, and smaller financial institutes may remain competitive.

\section{ENDNOTES}

[1] SANTOS (2000), pp. 5.

[2] ZUFFEREY (2000), pp. 35 and 79.

[3] LLEWELLYN (1999), pp. 13 and 22.

[4] LLEWELLYN (1999), pp. 13.

[5] KPMG INTERNATIONAL (2004).

[6] BÜHRER (2004), HUBLI (2004), MARTI (2004).

[7] ANDREWS/KLUMPES/MEEKS et al. (2000), pp. 4.

[8] FSA 2000, pp. 5-9.

[9] ALFON/ANDREWS (1999), pp. 15-16.

[10] ALFON/ANDREWS (1999), pp. 18 and ZUFFEREY (2000), pp. 92.

[11] HUBLI (2004), pp. 43-48 and MARTI (2004), pp. 57-58.

[12] SFBC (2004a).

[13] DÉROBERT (2004), pp. 34.

[14] Prevention of money laundering; Risk management; Equity/liquidity/accounting; Others (Independence of financial analysis, Market behaviour, Guidelines on portfolio management agreements, Fund distribution).

[15] Prudential regulation in the sense of an institutional rather than a functional or market regulation. Prudential regulation is ideally designed to prevent the insolvency of the supervised institutes through preemptive measures like capital requirements.

[16] With the exception of the canton Tessin where IAMS need to be licensed.

[17] HESS (1999), pp. 1431.

[18] About half of all IAMS in Switzerland are not associated to a professional association. VILLIGER (2001), pp. 19.

[19] ZOBL (1988), pp. 332 and 336.

[20] KPMG INTERNATIONAL (2004).

[21] HOFFMANN (2004), pp. 29.

[22] EU Directive 2001/107/EC (UCITS), article $5 \mathrm{~g} / 1 / \mathrm{c}$.

[23] ROTH (2004), pp 9.

[24] Today about $50 \%$ of the Swiss IAMS take out a liability insurance. BÜHRER (2004). 


\section{REFERENCES}

ALFON, I. and P. ANDREWS (1999): "Cost-Benefit Analysis in Financial Regulation", FSA Occasional Paper Series, No. 3, London.

ANDREWS, P., P. KLUMPES, G. MEEKS, et al. (2000): "Some Cost-Benefit Issues in Financial Regulation”, FSA Occasional Paper Series, No. 12, London.

ASPB: http://www.swissprivatebankers.com.

BÜHRER, CH. (2004): Untersuchung bei unabhängigen Vermögensverwaltern in der Schweiz, Swiss Banking Institute, University of Zürich, unpublished, Zürich.

DÉROBERT, M. Y. (2004): "Personengesellschaften verdienen eine bessere Behandlung", in: Die Volkswirtschaft, Das Magazin für Wirtschaftspolitik, Nr. 10, pp. 34-35.

ELLIEHAUSEN, G. E. (1998): "The Cost of Bank Regulation: A Review of the Evidence", in: Board of Governors of the Federal Reserve System (publ.), Federal Reserve Bulletin, Staff Study 171.

EUROPE ECONOMICS (2003): Costs of Compliance. A Report by Europe Economics, http://www. fsa.gov.uk/pubs/other/cost_compliance.pdf.

FRANKS, J. R., S. M. SCHAEFER and M. D. STAUNTON (1998): "The Direct and Compliance Costs of Financial Regulation", Journal of Banking and Finance 21, pp. 1547-1572.

FSA (2000). Practical Cost-Benefit Analysis for

Financial Regulators, http://www.fsa.gov.uk/pubs/ other/cba.pdf.

GEIGER, H. and I. HUBLI (2004): "Kosten der Bankenregulierung”, Der Schweizer Treuhänder 8, pp. 601-608.

HESS, M. (1999): "Zur Stellung des externen Vermögensverwalters im Schweizer Finanzrecht”, in: Aktuelle Juristische Praxis, pp. 1426-1434.

HOFFMANN, S. (2004): Standortbestimmung Finanzmarktregulierung: Wie viel und welche Regulierung tut den Banken und dem Finanzplatz gut?, Basel: Positionpaper of the Swiss Bankers Association.

HUBLI, I. (2004): "Regulatory Burden: Die Kosten der Regulierung von Vermögensverwaltungs- banken in der Schweiz", Working Paper 37 of the Swiss Banking Institute, University of Zürich, Zürich.

KPMG INTERNATIONAL (2004): Global Anti-Money Laundering Survey 2004. How Banks are facing up to the Challenge.

LLEWELLYN, D. (1999): "The Economic Rationale for Financial Regulation", FSA Occasional Paper Series, No. 1, London.

MARTI, E. (2004): "Die Regulierung der unabhängigen Effektenhändler in der Schweiz", Working Paper 38 of the Swiss Banking Institute, University of Zürich, Zürich.

ROTH, U. P. H. (2004): "Regulierung der NichtBanken-Finanzintermediäre, Speech at the general assembly of the Swiss Association of Independent Securities Dealers", http://www.swiss-banking.org/ en/referat_rou_040601.pdf.

SAAM: Unabhängige Vermögensverwaltung, http:// www.vsv-asg.ch/htm/htm_d/unabhaengig.htm.

SANTOS, J. A. C. (2000): "Bank Capital Regulation in Contemporary Banking Theory: A Review of the Literature", BIS Working Papers, No. 90, Basel.

SFBC (2004a): Umfang der Revisionsarbeiten bei Banken und Effektenhändlern-2002 Survey, http:// www.ebk.admin.ch.

SFBC (2004b): Bewilligte Banken und Effektenhändler (Stand 1.11.2004), http://www.ebk.admin.ch/d/ societe/dbeh.pdf.

SNB (2004): Die Banken der Schweiz 2003, Schweizerische Nationalbank, Zürich.

STRITTMATTER, M. (2003): Studie betreffend administrativen Auswirkungen des Geldwäschereigesetzes für Vermögensverwalter in der Schweiz, Schweizerisches Institut für Banken und Finanzen, Universität St. Gallen, unpublished, St. Gallen.

VILLIGER, K. (2001): Finanzmarktregulatorische Perspektiven, Speech at the general assembly of the Swiss Association of Asset Managers, http:// www.efd.admin.ch/d/dok/referate/2001/05/vsv.pdf.

ZOBL, D. (1988): "Der Vermögensverwaltungsauftrag der Banken", in: FORSTMOSER, P., (ed.), Innominatverträge: Festgabe zum 60. Geburtstag 
von Walter R. Schlüp, Polygraphischer Verlag, Zürich, pp. 319-335.

ZUFFEREY, J. B. (2000): Finanzmarktregulierung und -aufsicht in der Schweiz. Bern: Schlussbericht, EDMZ.

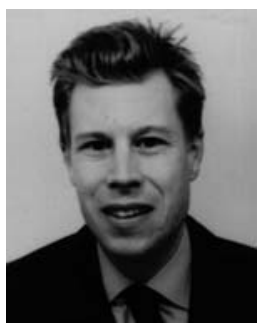

Christian Bührer, lic. oec. publ., born 1975 in Zürich finished his studies in Business Administration at the University of Zürich in autumn 2000. He worked in the banking and consulting industry and is currently a Research Assistant at the Swiss Banking Institute at the University of Zürich.

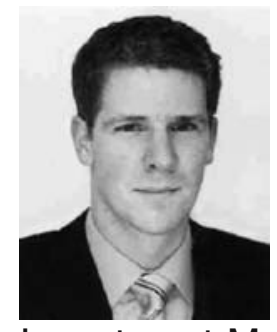

Ivo Hubli, lic. oec. publ., born 1977 in Zürich. After finishing his studies in Finance at the University of Zürich in spring 2004 he entered the alternative investment business currenty working for RMF Investment Management.

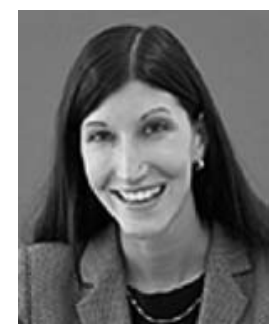

Eliane Marti, lic. oec. publ., born in 1979 in Zürich finished her studies in Business Administration at the University of Zürich in autumn 2004. Subsequently, she started to work as a fixed income fund analyst for UBS in Zürich. 